\title{
BEZPIECZEŃSTWO ENERGETYCZNE A BEZPIECZEŃSTWO WEWNĘTRZNE PAŃSTWA
}

\begin{abstract}
W artykule przedstawiono rolę bezpieczeństwa energetycznego w ogólnie pojmowanym bezpieczeństwie wewnętrznym państwa. Zagadnienie to wpisuje się w najnowsze trendy ujmowania bezpieczeństwa wewnętrznego zarysowywane i promowane m.in. przez Unię Europejską. Już nie tylko potencjał militarny, gospodarczy, ale również infrastruktura krytyczna, która zapewnia rozwój oraz zaspokojenie głównych potrzeb obywateli stanowi o potencjale bezpieczeństwa danego kraju.

Unijne prawo wyznacza kształt polityki energetycznej poszczególnych państw-członków. Jest ono efektem uzgodnień zawartych $w$ postanowieniach szczytu Unii Europejskiej w Lizbonie z marca 2000 r.; tak zwana strategia lizbońska zakładała osiągnięcie przez kraje członkowskie UE do 2010 r. pozycji najbardziej konkurencyjnej i dynamicznej gospodarki świata. Mimo tego, że w pierwotnych dokumentach strategii lizbońskiej nie uwzględniono energetyki, to jej ogromne znaczenie dla konkurencyjności unijnej gospodarki spowodowało, że na szczytach w Sztokholmie (2001), Barcelonie (2002) i w Brukseli (2003) podjęto decyzje związane z tym obszarem funkcjonowania państwa.

Energetyka, dywersyfikacja źródeł energii - to ważne elementy budowania bezpieczeństwa danego kraju. Tak ujęta problematyka bezpieczeństwa wewnętrznego państwa pokazuje wielopłaszczyznowość tego zagadnienia i skomplikowanie zagwarantowania bezpieczeństwa w zglobalizowanym świecie, gdzie gospodarka coraz częściej przestaje posiadać narodowość.
\end{abstract}

Słowa kluczowe: bezpieczeństwo energetyczne, rodzaje bezpieczeństwa, bezpieczeństwo wewnętrzne, zagrożenia w bezpieczeństwie energetycznym.

\section{WPROWADZENIE}

Bezpieczeństwo jest istotną wartością w każdym państwie oraz celem samym w sobie. Niezwykle ważnym środkiem do zrealizowania tego celu jest wprowadzenie do systemu bezpieczeństwa wewnętrznego państwa elementów bezpieczeństwa energetycznego. Dostęp do energii to podstawa funkcjonowania zarówno pojedynczego człowieka, jak i całej gospodarki.

\section{PODSTAWOWE POJĘCIA Z OBSZARU BEZPIECZEŃSTWA ENERGETYCZNEGO}

Fundamentalnymi aspektami bezpieczeństwa są: brak zagrożenia oraz poczucie pewności (obiektywne i subiektywne). O bezpieczeństwie mówi się wówczas, gdy „nie wy-

\footnotetext{
${ }^{1}$ Dr Marlena Lorek, Zakład Nauki o Bezpieczeństwie, Wydział Zarządzania, Politechnika Rzeszowska im. Ignacego Łukasiewicza, Aleja Powstańców Warszawy 8, 35-959 Rzeszów; e-mail: mlorek@prz.edu.pl.
} 
stępują jednocześnie: rzeczywiste zagrożenie (czynnik obiektywny) i jego poczucie (czynnik subiektywny) ${ }^{2}$.

„W znaczeniu ogólnospołecznym bezpieczeństwo obejmuje zaspokojenie potrzeb: istnienia, przetrwania, pewności, stabilności, całości, tożsamości (identyczności), niezależności, ochrony poziomu i jakości życia. Bezpieczeństwo, będąc naczelną potrzebą człowieka i grup społecznych, jest zarazem podstawową potrzebą państw i systemów międzynarodowych: jego brak wywołuje niepokój i poczucie zagrożenia"’3.

Analizując pojęcie bezpieczeństwa w ogóle, należy się skupić na jego rodzajowości, która jest wyznaczana przez poszczególne aspekty życia człowieka. Klasyfikację tę można przeprowadzić ze względu na kryterium podmiotowe, przedmiotowe lub podmiotowoprzedmiotowe ${ }^{4}$. Bezpieczeństwo $\mathrm{w}$ ujęciu podmiotowym będzie dotyczyć określonej grupy osób bądź państw, co implikuje wyodrębnienia bezpieczeństwa narodowego, międzynarodowego czy bezpieczeństwa obywateli. Natomiast w ujęciu przedmiotowym można wyróżnić następujące rodzaje bezpieczeństwa ${ }^{5}$ :

- atomowe,

- biologiczne,

- ekologiczne,

- ekonomiczne,

- energetyczne,

- epidemiologiczne,

- humanitarne,

- ideologiczne,

- kulturowe,

- militarne,

- polityczne,

- socjalne,

- społeczne.

Bezpieczeństwo energetyczne jest niekiedy uznawane jako element składowy bezpieczeństwa ekonomicznego, które związane jest z zagrożeniami dla dobrobytu państwa. Obejmuje ono ${ }^{6}$ :

- bezpieczeństwo dostaw surowców,

- bezpieczeństwo finansowe i kredytowe,

- bezpieczeństwo techniczno-przemysłowe,

- dostęp do rynków.

Ze względu na swoją wielowymiarowość bezpieczeństwo energetyczne należy uznać za odrębną dziedzinę bezpieczeństwa państwowego. Można je określić jako zdolność danego państwa do funkcjonowania bez zaburzeń związanych z fizyczną dostępnością

2 J. Stańczyk, Wspótczesne pojmowanie bezpieczeństwa, Warszawa 1996, s. 18.

${ }^{3}$ Zob. R. Zięba, Pojęcie $i$ istota bezpieczeństwa państwa $w$ stosunkach międzynarodowych, Warszawa 1989, s. 50.

${ }^{4}$ S. Pieprzny, Administracja bezpieczeństwa i porzadku publicznego, Rzeszów 2012, s. 12;

R. Rosicki, O pojęciu i istocie bezpieczeństwa, „Przegląd Politologiczny” 2010, No. 3, p. 24-32.

5 R. Zięba, Pozimnowojenny paradygmat bezpieczeństwa międzynarodowego [w:] Bezpieczeństwo międzynarodowe po zimnej wojnie, red. R. Zięba, Warszawa 2008, s. 15-39.

${ }^{6}$ J. Czaputowicz, Bezpieczeństwo międzynawowe, wspótczesne koncepcje, Warszawa 2012, s. 91. 
dostaw surowców energetycznych zaspokajających popyt państwa przy określonej cenie za dany surowiec ${ }^{7}$. Zgodnie z ustawą z 10 kwietnia 1997 r. - Prawo energetyczne ${ }^{8}$ bezpieczeństwem energetycznym jest stan gospodarki umożliwiający pokrycie bieżącego i perspektywicznego zapotrzebowania odbiorców na paliwa i energię w sposób technicznie i ekonomicznie uzasadniony przy zachowaniu wymagań ochrony środowiska. Bezpieczeństwo energetyczne ma wpływ na niemal każdy element prawidłowego funkcjonowania państwa, bowiem surowce energetyczne wpływają na możliwość działania organów państwowych na polu politycznym, gospodarczym oraz społecznym czy ekologicznym.

„Zielona Księga” podaje, że bezpieczeństwo energetyczne to „nieprzerwana fizyczna dostępność produktów energetycznych na rynku, po przystępnej dla wszystkich konsumentów cenie, w poszanowaniu środowiska i z zapewnieniem zrównoważonego rozwoju”'. „Zielona Księga. Europejska strategia na rzecz zrównoważonej, konkurencyjnej i bezpiecznej energii" wskazuje na pilne potrzeby inwestycyjne związane z zaspokojeniem zapotrzebowania na energii i wymianą starzejącej się infrastruktury. Międzynarodowa Agencja Energii uważa bezpieczeństwo energetyczne za „nieprzerwaną fizyczną dostępność dostaw, po przystępnej cenie, wykorzystywaną w zgodzie ze środowiskiem"10. Center of Strategic and International Studies twierdzi, iż „bezpieczeństwo energetyczne to ciągła zdolność państwa do utrzymywania swego funkcjonowania bez poważnych zaburzeń"11.

W zakresie bezpieczeństwa energetycznego można wyróżnić kilka jego składników, a wśród głównych należy wskazać ${ }^{12}$ :

1. bezpieczeństwo polityczne - przekłada się na zapewnienie przez państwa zarówno samego dostępu do głównych źródeł energii, jak i zagwarantowanie prawidłowego oraz niezakłóconego funkcjonowania urządzeń służących adaptacji energii;

2. bezpieczeństwo techniczne - jest związane $\mathrm{z}$ infrastrukturą techniczną, która jest utrzymywana w należytym stanie technicznym i eksploatowana w sposób zapewniający właściwe jej funkcjonowanie;

3. bezpieczeństwo technologiczne - wiąże się z zapewnieniem odpowiednich standardów w zakresie jakości dostarczanej energii; działaniami państw zmierzających do wykorzystywania coraz to nowych technologii i źródeł, z jakich można pozyskać energię; prowadzeniem badań naukowych czy podnoszeniem poziomu kompetencji kadr w systemie sektora energetycznego.

Głównym podmiotem bezpieczeństwa energetycznego jest państwo. W ujęciu przedmiotowym na definicję bezpieczeństwa energetycznego składają się następujące aspekty: polityczny, gospodarczy, ekologiczny.

Aspekt polityczny powiązany jest z koniecznością realizowania przez państwo działań, które zmierzają do wyeliminowania lub ograniczenia możliwości wywierania jakiejkolwiek presji politycznej przez podmioty mające status dostawców energii. Celem tych działań jest osiągnięcie stabilnego i pewnego dostępu do surowców energetycznych przez

\footnotetext{
7 Ibidem.

8 Tekst jedn. Dz.U. z 2017 r., poz. 220 ze zm.

9 www. orka.sejm.gov.pl (dostęp: 23.07.2017 r.).

${ }^{10}$ www.bezpeuro.republika.pl (dostęp: 23.07.2017 r.).

11 Ibidem.

${ }^{12}$ G. Bartodziej, M. Tomaszewski, Polityka energetyczna i bezpieczeństwo energetyczne, Racibórz 2009, s. 74.
} 
zapewnienie prawidłowych relacji politycznych zarówno z państwami, które dysponują zasobami nośników energii, jak i tymi, przez terytoria których odbywa się ich transport.

Aspekt gospodarczy odnosi się natomiast głównie do cech, które określają prawidłowe funkcjonowanie sektora energetycznego, i związany jest z kondycją gospodarki narodowej, obserwuje się zależność, że im wyższy poziom bezpieczeństwa energetycznego, tym stabilniejsza gospodarka ${ }^{13}$. Bezpieczeństwo energetyczne jest istotne w systemie gospodarczym każdego państwa, ponieważ ma znaczenie strategiczne zarówno pod względem szeroko pojętego bezpieczeństwa wewnętrznego i narodowego, jak i stabilnego rozwoju gospodarczego.

Aspekt ekologiczny odnosi się do ograniczania negatywnych skutków oddziaływania rynku energetycznego na środowisko naturalne. Obejmuje ono zarówno etapy gospodarowania energią, na którą składa się pozyskiwanie nośników energii, ich przetwarzanie, transport, jak i jej konsumpcję ${ }^{14}$. Na każdym tym etapie objawiają się specyficzne zagrożenia, które wymagają osobnych przeciwdziałań. W tym miejscu bezpieczeństwo energetyczne zazębia się z bezpieczeństwem ekologicznym.

W dalszej części artykułu zaprezentowane zostanie znaczenie bezpieczeństwa energetycznego w kontekście bezpieczeństwa wewnętrznego państwa.

\section{ZNACZENIE BEZPIECZEŃSTWA ENERGETYCZNEGO W KONTEKŚCIE BEZPIECZEŃSTWA WEWNĘTRZNEGO PAŃSTWA}

Bezpieczeństwo energetyczne w aspekcie współczesnych stosunków międzynarodowych odgrywa ogromną rolę i wpływa na decyzje podejmowane w sferze zabezpieczenia państw w zakresie surowców energetycznych. Państwa, które posiadają znaczące zasoby energetyczne, takie jak węgiel kamienny, ropa naftowa i gaz ziemny, odgrywają kluczową rolę $w$ tej sferze stosunków międzynarodowych i dzięki temu zajmują wysoką pozycję konkurencyjną, a co za tym idzie - również niekiedy dyktują warunki w zakresie sposobu i formy udostępniania posiadanych surowców, których są eksporterami.

Obecnie Europa nie stworzyła w pełni konkurencyjnych i samodzielnych wewnętrznych rynków energii. Aby to osiągnąć, należy mieć na względzie trzy elementy:

- trwałość polityki bezpieczeństwa energetycznego,

- konkurencyjność polityki bezpieczeństwa energetycznego,

- bezpieczeństwo zaopatrzenia w energię.

Zagrożenie to ,sytuacja, w której pojawia się prawdopodobieństwo powstania stanu niebezpiecznego dla otoczenia. Przyjmując za podstawę dziedziny, w których może wystąpić zagrożenie, wyróżnia się zagrożenia militarne i niemilitarne. Wśród zagrożeń niemilitarnych można z kolei wyróżnić zagrożenie polityczne, zagrożenie ekonomiczne (gospodarcze), zagrożenie psychospołeczne, zagrożenie ekologiczne, zagrożenie wewnętrzne i inne"15. Zagrożenie to „realna możliwość zastosowania przemocy zbrojnej”"16.

13 A. Kędzielawa, Uwarunkowania rynkowe bezpieczeństwa energetycznego, „Elektroenergetyka” 2005, nr 1, s. 1.

${ }^{14}$ G. Wojtkowska-Łodej, Energia i środowisko, procesy dostosowań w świetle przyszłego członkowska Polski w Unii Europejskiej, Warszawa 1998, s. 4.

15 J. Kaczmarek (red.), Stownik terminów z zakresu bezpieczeństwa narodowego, Warszawa 2008, s. 172-173.

16 B. Balcerowicz, Strategia obronna państwa, Warszawa 1994, s. 13. 
Zagrożeniem jest „możliwość występowania jednego z negatywnie wartościowanych zjawisk"17, zatem można stwierdzić, że tworząc ogólną teorię bezpieczeństwa należy uwzględnić trzy główne obszary problemów ściśle powiązanych ze sobą.

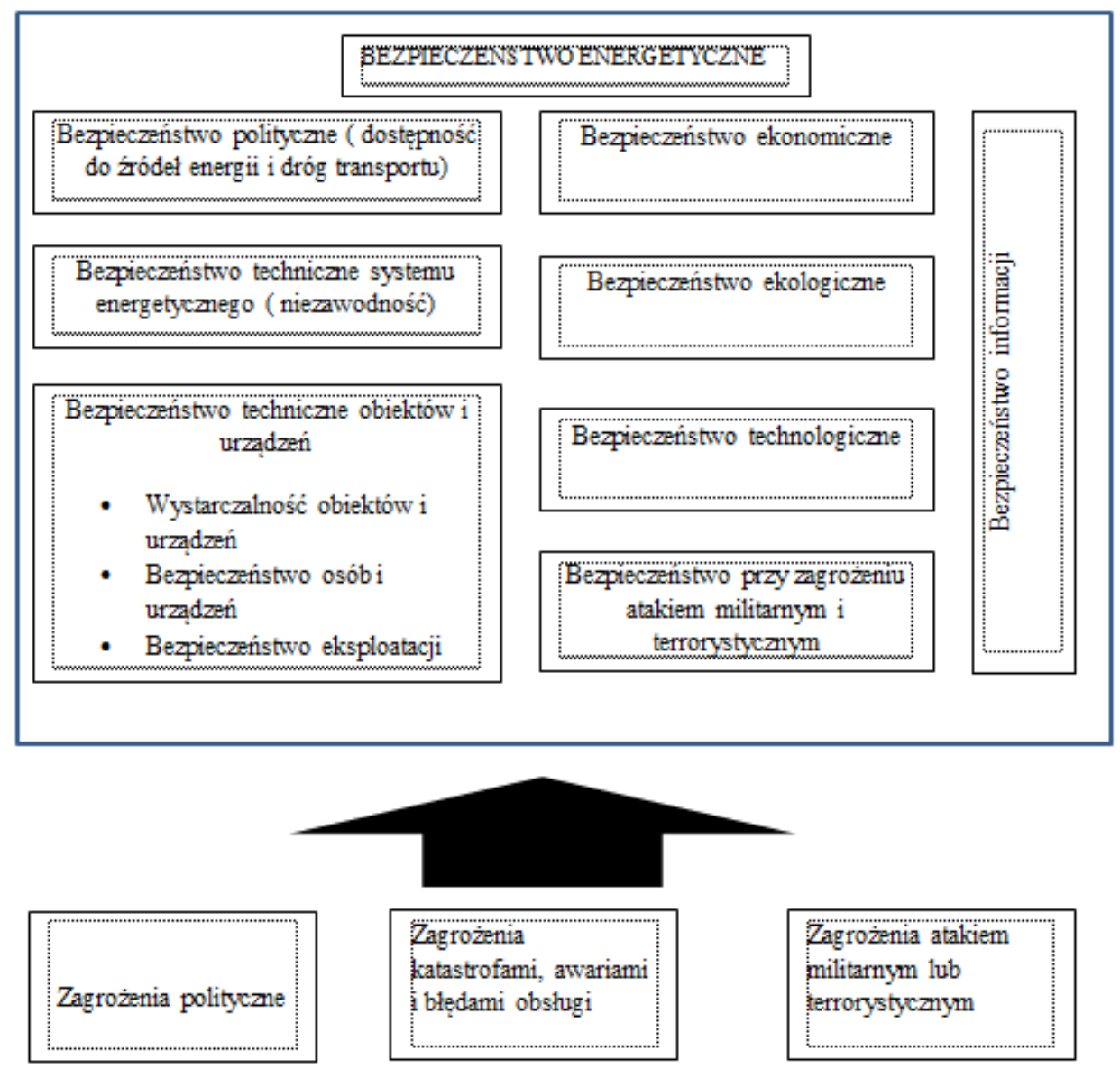

Rys. 1. Struktura bezpieczeństwa energetycznego

Źródło: opracowanie własne na podstawie: G. Bartodziej, M. Tomaszewski, Polityka energetyczna...

Zagrożenia związane $\mathrm{z}$ bezpieczeństwem energetycznym można podzielić na następujące kategorie:

- według charakteru zagrożeń: zagrożenia techniczne, ekonomiczne, polityczne, asymetryczne i geologiczne,

- według źródeł: zagrożenia zewnętrzne i wewnętrzne,

- według czasu" zagrożenia krótko- i długoterminowe.

${ }^{17}$ R. Zięba, Instytucjonalizacja bezpieczeństwa europejskiego, Warszawa 2004, s. 28. 
Do zagrożeń technicznych zaliczyć można np. awarię elektrowni bądź eksplozję rurociągu. Przeciwdziałanie tym zagrożeniom polega na zachowaniu właściwych standardów bezpieczeństwa oraz inwestowaniu w modernizację i unowocześnianie infrastruktury energetycznej. Zagrożeniami ekonomicznymi są m.in. strajki lub nagłe wzrosty cen czy też brak odpowiedniej przepustowości sieci przemysłowej. Zagrożenia polityczne to:

- blokady, czyli tzw. Chokepoint,

- naruszanie kontraktów,

- ograniczanie produkcji,

- wprowadzanie embarga na dostawy surowców.

Zagrożeniom politycznym można przeciwdziałać za pomocą m.in.:

- dywersyfikacji bilansu energetycznego, źródeł transportu i tras ich dostarczania,

- prowadzenia dialogu między importerami i eksporterami,

- tworzenia rezerw strategicznych,

- zapewniania elastyczności kontraktów.

Zagrożenia asymetryczne są związane $\mathrm{z}$ atakami terrorystycznymi na pola naftowe, rafinerie, elektrownie czy systemy informatyczne sektora energetycznego. Ostatnim rodzajem zagrożeń są zagrożenia geologiczne, czyli wyczerpywanie się zasobów surowców energetycznych na świecie. Aby im zapobiec, należy wdrażać energooszczędną technologię oraz wykorzystywać odnawialne źródła energii.

Bardzo ważne jest uświadomienie sobie, że skutki zagrożenia bezpieczeństwa energetycznego są bardzo dotkliwe nie tylko dla sektora gospodarczego. Przejawiają się one na wielu płaszczyznach funkcjonowania współczesnych państw. Dotykają każdego obywatela z osobna i całą populację.

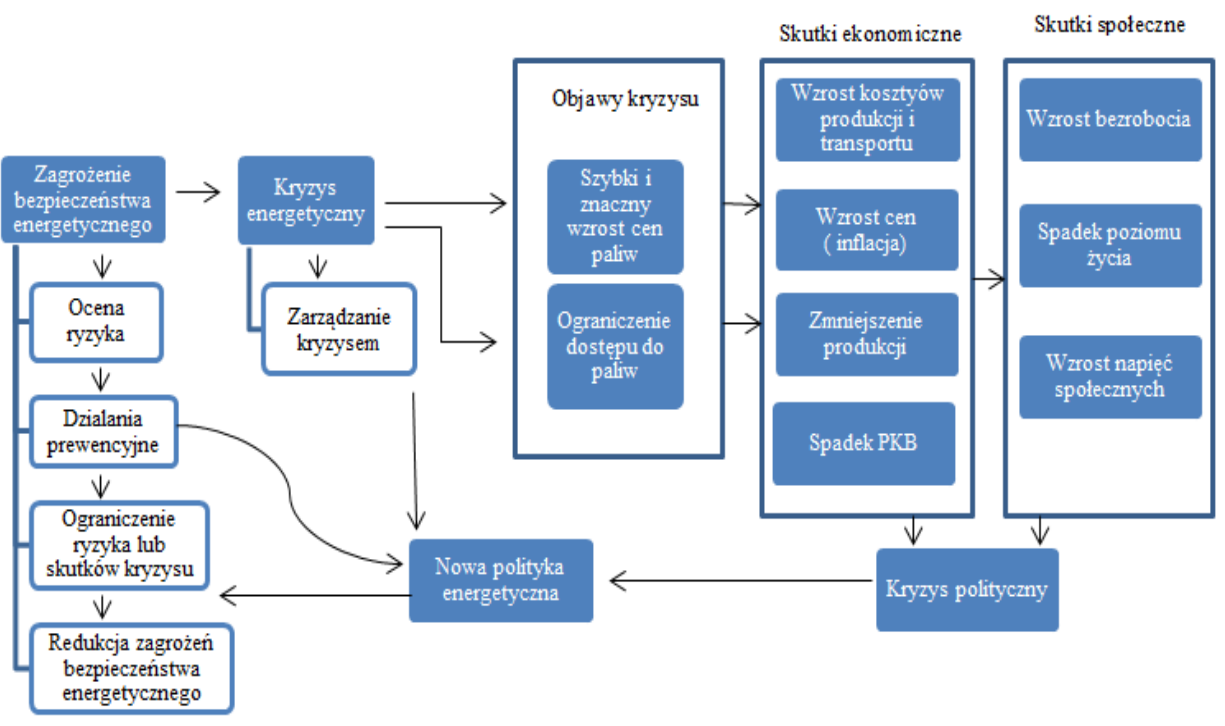

Rys. 2. Skutki zagrożenia bezpieczeństwa energetycznego

Źródło: opracowanie własne na podstawie G. Bartodziej, M. Tomaszewski, Polityka energetyczna... 
Na rysunku 2 przedstawiono złożoność skutków, jakie niosą ze sobą zagrożenia w sektorze energetycznym. Ich wzajemne powiązanie i sukcesywne oddziaływanie każdego z nich na odrębny segment tego sektora wskazuje na to, iż nie należy lekceważyć żadnego, nawet wydawałoby się najmniejszego zagrożenia, gdyż w połączeniu z kolejnymi czynnikami może wpływać destrukcyjnie na funkcjonowanie całego systemu sektora energetycznego.

Dlatego tak ważne jest dbanie o zapewnienie wystarczającego, adekwatnego do stopnia rozwoju danego społeczeństwa poziomu bezpieczeństwa energetycznego.

Najważniejszymi instrumentami, które służą zapewnieniu należytego poziomu bezpieczeństwa energetycznego, są:

- członkostwo w organizacjach międzynarodowych,

- dywersyfikacja źródeł dostaw energii,

- ograniczenie dostępu innym podmiotom do wewnętrznego rynku energetycznego,

- ratyfikowanie umów międzynarodowych, z których wynikają zasady regulujące funkcjonowanie ponadnarodowego systemu energetycznego,

- rozwój właściwej infrastruktury techniczne niezbędnej do prawidłowego funkcjonowania systemów przesyłu i produkcji,

- stworzenie odpowiedniego nadzoru nad rynkiem energetycznym,

- tworzenie rezerw surowców energetycznych,

- utrzymanie właściwej struktury własnościowej przedsiębiorstw energetycznych,

- zawieranie długoterminowych umów na dostawy surowców energetycznych.

Biorąc pod uwagę bezpośrednie czynniki modelujące poziom bezpieczeństwa energetycznego, należy tutaj wskazać przede wszystkim takie, jak ${ }^{18}$ :

- moc dystrybucyjna oraz przesyłowa w zakresie posiadanej infrastruktury surowcowej oraz energetycznej,

- poziom stabilności systemu politycznego oraz gospodarczego,

- poziom złóż (zasobów) surowców energetycznych,

- poziom związany z wydobyciem surowców energetycznych,

- poziom związany z wytwarzaniem energii,

- poziom związany ze stopniem mocy, jaką dysponuje elektrownia,

- różnorodność w zakresie dostaw surowców i energii w zakresie podstawowych kierunków oraz ich źródeł,

- system transportu surowców,

- system umożliwiający normowanie działania sektora energetycznego,

- system umożliwiający realizację procesu magazynowania,

- wahania w sferze stabilności sytuacji międzynarodowej.

W ostatnich latach szczególne miejsce w tym względzie zajmuje dywersyfikacja źródeł surowców energetycznych.

Dywersyfikacja to pojęcie oznaczające rozszerzenie poszczególnej sfery działania danej organizacji poprzez m.in. wprowadzanie nowych rodzajów wyrobów, nowych dostawców, nowych odbiorców czy też wdrażanie nowych metod ${ }^{19}$. Dywersyfikacja jest pojęciem używanym zarówno w sferze ekonomicznej, jak i energetycznej. Dywersyfika-

${ }^{18}$ K. Kałążna, R. Rosicki, Wymiary bezpieczeństwa energetycznego Unii Europejskiej, Poznań 2010, s. 18-19.

19 A. Koźmiński, W. Piotrowski, Zarządzanie teoria i praktyka, Warszawa 2005, s. 757. 
cja, jako element bezpieczeństwa energetycznego, prowadzi do zróżnicowania źródeł energii, szlaków transportowych nośników energii oraz uniezależnienia się od monopolistycznych dostawców i pośredników. Pozwala uniezależnić się państwom od jednego dostawcy, za którym często stoi konkretne inne państwo. Ale dywersyfikacja nie jest jedynym środkiem utrzymania wysokiego poziomu bezpieczeństwa. Należy wdrażać również takie działania, jak $^{20}$ :

- działania w sferze zwiększania udziału odnawialnych źródeł energii w bilansie energetycznym państw,

- minimalizacja kosztów,

- ochrona konkurencji oraz eliminowanie ryzyka monopolizacji rynku energetycznego,

- optymalne i efektywne wykorzystywanie energii,

- prowadzenie wspólnych inwestycji w sektorze energetycznym,

- rozwój nowych technologii w zakresie przetwarzania energii,

- wdrażanie nowych procesów technologicznych,

- wzrost sprawności działania urządzeń przesyłowo-produkcyjnych,

- zawieranie umów między państwami (w tym określenie zasad finansowania i opłat),

- zredukowanie popytu na energię,

- zwiększanie stopnia odporności infrastruktury przesyłowej i urządzeń na zagrożenia oraz katastrofy.

Krytyczna infrastruktura techniczna Polski (w tym omawiana w niniejszym artykule energetyka) jest już w znacznym, chociaż nadal odbiegającym od standardów światowych, stopniu zinformatyzowana. To z jednej strony ułatwia funkcjonowanie tej gałęzi przemysłu, z drugiej strony jednak wystawia ją na nowe typy zagrożeń. W związku z tym jednym z kolejnych gwarantów bezpieczeństwa energetycznego kraju jest zapewnienie właściwej ochrony i mechanizmów przeciwdziałania zagrożeniom cyberterroryzmu.

Cyberterroryzm jest działaniem bardzo agresywnym i asymetrycznym, które przejawia się zastraszaniem społeczności internetowej nowymi formami zagrożeń, np. sparaliżowania systemów komputerowych sterujących zaopatrzeniem w energię elektryczną, atakami hakerów na infrastrukturę techniczną.

Cyberprzestępcy działają w wirtualnym świecie, ale skutki ich działania są realne. We współczesnym świecie, w którym poszczególne instytucje i organizacje stanowią system naczyń połączonych, jedne zamach może pociągnąć za sobą nieprzewidywalne skutki o ogromnym rozmiarze i szerokim zasięgu.

Bezpieczeństwo energetyczne warunkuje prawidłowy rozwój państwa, nie tylko gospodarczy. Jeśli zagrożone jest bezpieczeństwo energetyczne, przy współczesnym stopniu technicyzacji i rozwoju techniki grozi to destabilizacją danego kraju i jednocześnie staniem się przez nie łatwym polem ataku ze strony innych państw. Budowanie silnego energetycznie państwa jest gwarantem jego bezpieczeństwa ekonomicznego, ale w dużym stopniu i militarnego. Zaspokojenie potrzeb obywateli stanowi gwarancję spokoju i porządku publicznego.

Obecnie bezpieczeństwo energetyczne, obok konkurencyjności i ochrony środowiska, jest jednym $\mathrm{z}$ trzech priorytetów polityki energetycznej Unii Europejskiej. Prawidłowo

${ }^{20}$ G. Bartodziej, M. Tomaszewski, Polityka energetyczna..., s. 105. 
prowadzona polityka bezpieczeństwa energetycznego poszczególnych państw pozwala na ich autonomię i niezależność, co wpływa na rozumiane tradycyjnie bezpieczeństwo wewnętrzne. Zaspokojenie potrzeb obywateli gwarantuje ich zadowolenie i niewszczynanie protestów czy rewolucji.

\section{PODSUMOWANIE}

Współczesne bezpieczeństwo wewnętrzne jest osadzone nie tylko na klasycznych już filarach, takich jak porządek publiczny, bezpieczeństwo lokalne, bezpieczeństwo jednostki. W zglobalizowanym świecie prawidłowe funkcjonowanie państw jest uzależnione w dużym stopniu od bezpieczeństwa energetycznego. Stanowi ono warunek rozwoju gospodarczym i technologicznym danego kraju, a w konsekwencji plasuje go wysoko w rankingu państw o dużym stopniu bezpieczeństwa zewnętrznego.

Bezpieczne energetycznie państwo rozwija się w sposób harmonijny i niezagrożony paraliżem wewnętrznym na skutek niedoborów surowców energetycznych. Bezpieczeństwo energetyczne w sposób pozytywny wpływa na pozostałe obszary bezpieczeństwa przedmiotowego, stanowiąc system naczyń połączonych wzajemnie warunkujących bezpieczeństwo danego państwa w ujęciu holistycznym.

Państwa Unii Europejskiej, aby osiągnąć pożądany poziom bezpieczeństwa energetycznego, powinny podjąć szereg określonych działań. Przede wszystkim powinny być one ukierunkowane na zwiększenie konkurencyjności unijnego sektora energetycznego. Warunkiem tego jest stworzenie jednakowych warunków działalności dla wszystkich uczestników runku energii Unii Europejskiej. W tej chwili górę biorą koniunkturalne interesy poszczególnych krajów członkowskich. Kluczowe znaczenie ma zwiększenie pewności dostaw na oczekiwanym poziomie. Wiąże się to z zapewnieniem stabilnych warunków, które umożliwią pokrycie bieżącego i przyszłościowego zapotrzebowania gospodarek krajów Unii Europejskiej.

\section{LITERATURA}

[1] Balcerowicz B., Strategia obronna państwa, Warszawa 1994.

[2] Bartodziej G., Tomaszewski M., Polityka energetyczna i bezpieczeństwo energetyczne, Racibórz 2009.

[3] Czaputowicz J., Bezpieczeństwo międzynawowe, wspótczesne koncepcje, Warszawa 2012.

[4] Kaczmarek J. (red.), Stownik terminów z zakresu bezpieczeństwa narodowego, Warszawa 2008.

[5] Kałążna K., Rosicki R., Wymiary bezpieczeństwa energetycznego Unii Europejskiej, Poznań 2010.

[6] Kędzielawa A., Uwarunkowania rynkowe bezpieczeństwa energetycznego, „Elektroenergetyka" 2005, nr 1.

[7] Koźmiński A., Piotrowski W., Zarządzanie, teoria i praktyka, Warszawa 2005.

[8] Pieprzny S., Administracja bezpieczeństwa i porządku publicznego, Rzeszów 2012.

[9] Rosicki R., O pojęciu i istocie bezpieczeństwa, „Przegląd Politologiczny” 2010, No. 3.

[10] Stańczyk J., Wspótczesne pojmowanie bezpieczeństwa, Warszawa 1996, s. 18.

[11] Ustawa z 10 kwietnia 1997 r. - Prawo energetyczne (tekst jedn. Dz.U. z 2017 r., poz. 220 ze zm.). 
[12] Wojtkowska-Łodej G., Energia i środowisko, procesy dostosowań w świetle przysztego członkowska Polski w Unii Europejskiej, Warszawa 1998.

[13] Zięba R., Instytucjonalizacja bezpieczeństwa europejskiego, Warszawa 2004.

[14] Zięba R., Pojęcie i istota bezpieczeństwa państwa w stosunkach międzynarodowych, Warszawa 1989.

[15] Zięba R., Pozimnowojenny paradygmat bezpieczeństwa międzynarodowego [w:] Bezpieczeństwo międzynarodowe po zimnej wojnie, red. R. Zięba, Warszawa 2008.

[16] www.orka.sejm.gov.pl (dostęp: 23.07.2017 r.).

[17] www.bezpeuro.republika.pl/ (dostęp: 23.07.2017 r.).

[18] repozytorium.amu.edu.pl (dostęp: 23.07.2017 r.).

\section{ENERGY SECURITY AND INTERNAL SECURITY OF STATE}

This article presents the role of energy security in the generally understood internal security of the state. This issue is a part of the latest trends in the recognition of internal security outlined and promoted, among others by the European Union. Not only military, economic, but also critical infrastructure, which ensures development and satisfaction of the main needs of citizens, is the security potential of a given country.

EU law determines the shape of the energy policy of individual member states. It is the result of the arrangements contained in the provisions of the European Union summit in Lisbon of March 2000. The so-called Lisbon Strategy assumed the achievement by the EU Member States by 2010 the position of the most competitive and dynamic economy in the world. Despite the fact that the original documents of the Lisbon Strategy did not include energy, its enormous significance for the competitiveness of the EU economy meant that decisions were taken at the summits in Stockholm (2001), Barcelona (2002) and Brussels (2003) related to this area of the functioning of the state.

Energy, diversification of energy sources - these are important elements of building the security of a given country. The issue of the internal security of the country thus presented shows the multilevel nature of this issue and the complexity of guaranteeing security in a globalized world, where the economy increasingly ceases to possess nationality.

Keywords: energy security, types of security, internal security, threats to energy security.

DOI: $10.7862 /$ rz.2017.mmr.29

Tekst złożono w redakcji: grudzień 2017 r.

Przyjęto do druku: grudzień 2017 r. 